ACTIVITIES OF ALI PRIMROSE INSEC'TS

\begin{tabular}{|c|c|c|c|c|}
\hline & $\begin{array}{l}\text { Known Feeders on or } \\
\text { in during one or more } \\
\text { stages. }\end{array}$ & $\begin{array}{l}\text { Flower } \\
\text { visitors }\end{array}$ & $\begin{array}{l}\text { Found on follage or } \\
\text { stems. Some are prob- } \\
\text { ably feeders. }\end{array}$ & Totals \\
\hline Homoptera & $\sigma_{-1.5}$ & & 4 & 13 \\
\hline Hemiptera ................. & 1 & & 15 & 16 \\
\hline Coleoptera & 13 & & 32 & 45 \\
\hline Lepidoptera & 13 & 1 & & 14 \\
\hline Hymenoptera* & 1 & 10 & 9 & 20 \\
\hline Diptera* & 1 & 1 & 2 & 4 \\
\hline 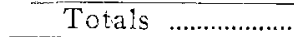 & 38 & 12 & 62 & 112 \\
\hline
\end{tabular}

*Parasites not incluced

Thus of a total of I I species, 38 or over one third utilize the plants for food purposes, many of then bcing present at the same time and others succeeding each other throughout the growing season. Yet in spite of almost constant and in many cases severe infestations, the growth of the plant is hardly ever visibly impaired and the insect visitations appear to be negligible happenings in the life of the plant. In spite of the injury to the rosette, the main stalk shoots up the following season. In spite of being tunneled from base to tip, it produces branches and leaves which are in turn riddled by leaf feeders. Flowers are produced profusely in spite of the bud injury and while many seed capsules are damaged, plenty escape. Hundreds of plants infested in all degrees were examined and aside from a small amount of fasciation, a small amount of distortion and a slight stunting which may have been due to other causes, no apparent or serious setback in the growth was observed. Infested plants developed, flowcred, produced sced and died more or less the same as uninfested plants. Lnder such conditions, the results to many plants other than primrose would probably be more or less fatal, but the primroses are evidently vigorous enough to outgrow the injuries of a host of insects.

\title{
NOTES ON NEW JERSEY HETEROCERA WITH DESCRIPTIONS OF ONE NEW SPECIES AND TWO NEW FORMS.
}

BY I. II. BEN J A MITN,

Agricultural College, Mississippi.

During the summer of IgIg the writer spent almost every week end in the New Jersey Pine Barrens, mainly at Brown's Mills in the Pines. Besides many rarities, the following new forms and one new species were taken. The types of these were very carefully compared at the collection of Dr. William Barnes by the author, and in order to eliminate any chance of error, checked by Dr. A. W. Lindsey.

\section{Eriopyga (Orthodes) lindseyi n. sp.}

Head, thorax and ground color of the fore-wings concolorously reddish, with a tendency toward ochreous and with a strong satiny luster. Antennae simple, ciliated, cilia in block like pattern on basal segments, longer seare visible on apical segments. Prothorax with a small, spreading somewhat divided crest; metathorax with a very small divided crest, or at least a trace of one pro- 
duced by hair tuftings. A few blackish scales tend to form a black line at the base of the prothoracic crest, and another on collar. Fore-wings with all lines double, and filled in with less reddish and more ochreous color than the ground, as are the reinforms and orbiculars. Subbasal line waved; transverse anterior waved; rather indistinct; orbicular small, round; reniform kidney shaped; two small white spots, one on each side of the reniform at its base, tending to become semi-confluent by the presence of a few white scales between them; transverse posterior line strongly outcurved from costa to vein 4, then incurved toward inner margin, slightly drawn out on the inner margin, thus forming a complete $S$; a suggestion of minute ochreous spots on some of the veins in the subteminal space, subterminal line oblique inwardly at costa, outwardly so in radial region, inwardly again in medial area, thus forming a rough reversed $Z$, below which it is evenly outcurved, finally projected to the inner margin as another outcurved scollop, a terminal row of minute black dots between the veins, which of themselves possess a scattering of black scales, fringe concolorous with the ground. Secondaries whitish with considerable fuscous shading; the terminal border marked by a thin, blackish line composed of elongated dots, fringe light at base and tips, a broad, dusky line through center; discoidal spot visible, probably mainly showing through from under side; veins somewhat dusky. Beneath: both wings whitish-fuscous, with discoidal spot and common line darker, dusky: a row of terminal spots between the veins on both wings; cell of fore-wing sparsely clothed with long hair. Sexes identical.

Type Locality: Brown's Mills in the Pines and I o Overbrook, N. J.; also 20ิ, I 9 , Barnes Coll, Pitman, N. J.

No. and Sexes of Types: Holotype A. Allotype $\$, 29$ Paratypes of $q$. Dates of Capture: V, VII, TX.

Types in: Collection of Author, and Barnes; also I Paratype, U. S. N. M.

This inscet to some extent resembles vecors, irrorata, pucrilis and when badly rubbed-furfurata, but seems abundantly distinct. The vestiture is far more scaly than is typical for members of the group Orthodes, and the satiny luster to the wings more pronounced. The vestiture is so scaly that the insect might well be placed in the genus Mamestra (Polia) were it not for its general appearance, resemblance, and apparent close relationship in all other characters to described nembers of the group Orthodes.

\section{Chytonix sensilis form macdonaldi form nov.}

Sir George Hampson places Chytonix sensilis in that group of the genus Chytonix having simple antennae in the male sex. However; the Cat. Lep. Phal., B. M.. seems to indicate that he did not know the male, which is similar to the female in pattern and maculation, but the antennae are laminate, the laminations almost forming short pectinations. Two males of the typical form were taken; and also one female without the white spot below the black streak connecting the transverse anterior and the transverse posterior lines in the submedian fold. This corresponds to ab. 1. of Hampson. One male and two females lacked the black streak, and in these the white spot is completely diffused by mixing with a suffusion of whitish scaling in the medial area. The resulting insect scarcely resembles the trpical form, and nay henceforth be known 
ander the form name macdonaldi, in remembrance of the many nights in the Pine Barrens during which Neil F. MacDonald, B. Chem., assisted untiringly the work of the author.

The general condition of all the specimens of this form taken is none the best. The females are in better condition than the male, and hence one of these is designated the holotype. This specimen has the transverse anterior and transverse posterior lines spaced a little further apart on the inner margin than is typical of $C$. sensilis. The male allotype and female paratype are normal in this respect.

Type Locality: Brown's Mills in the Pines, N. J.

No. and sexes of Types: Holotype $q$, Allotype ô, I Paratype $q$.

Typesin: Collection of Author.

\section{Olene atomaria form aridensis form nov.}

Size, lines and ordinary spots similar to O. atomaria. Female: forewing; basal area filled in with chocolate-brown to the transverse anterior line; subterminal area similarly filled; the medial area pale, olivaccous, with tendencies to blueish in some specimens and greenish in others, more suffused with color basally and inwardly. This gives a general impression of $O$ cinnamomea, but the size is larger and it matches in no other details. The reniform spot is strongly outlined with a fine chocolate-brown line, and is filled in paler than the pale medial area. As usual with species of this genus the basal edge of this spot is strongly marked. Hind wings an even medium brown with only the discal spot showing in some specimens, while in others a trace of a shade line is to be found. In this respect as well as in the peculiar coloration of the forewings, the form differs considerably from typical $O$. atomaria. Under side with discoidal spot, and shade line half way between spot and outer margin. Male: fore-wing with the basal area strongly tinged with purple; the subterminal area lighter brown than in the female, with a purplish and white patch on anal region; otherwise similar to the female, except that there is a waved line of the same color as the medial area through the basal brown area, thus cutting this into two parts. On the underside, the spots and lines are similar to the same ones in the female, but somewhat more suffused and broader, with the line on the fore-wing somewhat nearer to the spot.

This form is described mainly at the suggestion of Dr. William Barnes. At Brown's Mills in the Pines, N. J., atomaria runs to two forms; one much lighter than typical, more suffused, and with much less brown on the fore-wings. Of this form I have two specimens: $\delta \&$, the of taken 3 I-VIII-19, the o 5-VIII19. 'The other form is described above.

Type Locality: Brown's Mills in the Pines. N. I.

No. and sexes of Types: Holotype $q$, Allotype $\hat{o}$, Paratypes I $q$ q $q$, also I egg from Holotype.

Dates of Capture: August.

Types in: Collection of Author; 2 Paratypes and egg, Collection of Cornell University, 2 Paratypes, Collection Wm. Barnes. 